\title{
Article \\ A Systematic Review of Permeable Pavements and Their Unbound Material Properties in Comparison to Traditional Subbase Materials
}

\author{
Dansani Vasanthan Muttuvelu ${ }^{1,2, *,+} \mathbb{D}$ and Erik Kjems ${ }^{1,+}$ \\ 1 Division of Civil \& Environmental Engineering, Aalborg University, Thomas Manns Vej 23, \\ 9220 Aalborg, Denmark; kjems@build.aau.dk \\ 2 Department of Traffic, Roads and Harbours, WSP Denmark A/S, 2630 Taastrup, Denmark \\ * Correspondence: dvm@build.aau.dk \\ $+\quad$ The first author has written the entire draft version of the paper and revised it according to comments from \\ the second author.
}

Citation: Muttuvelu, D.V.; Kjems, E. A Systematic Review of Permeable Pavements and Their Unbound Material Properties in Comparison to Traditional Subbase Materials. Infrastructures 2021, 6, 179. https://doi.org/10.3390/ infrastructures6120179

Academic Editor: Rui Micaelo

Received: 27 October 2021

Accepted: 14 December 2021

Published: 16 December 2021

Publisher's Note: MDPI stays neutral with regard to jurisdictional claims in published maps and institutional affiliations.

Copyright: () 2021 by the authors. Licensee MDPI, Basel, Switzerland. This article is an open access article distributed under the terms and conditions of the Creative Commons Attribution (CC BY) license (https:// creativecommons.org/licenses/by/ $4.0 /)$.

\begin{abstract}
This paper is a literature review focused on permeable pavements and especially the permeable subbase material. Run-off water from the surface is traditionally let through a drainage system, and the roads are kept dry. Due to climate changes, heavy precipitation and high-intensity rainfalls are putting pressure on the infrastructure. Traditionally, water in subbase materials reduces the resilient E-moduli and the lifespan of the pavement design. Studies show that increasing saturation reduces the bearing capacity of a traditional subbase material. Unbound materials with highly grained fines and high moisture content have higher tendency to show reduced resilient E-moduli. One study was found where the E-moduli of five different coarse grained aggregates used in permeable pavements were examined through a triaxial test. It was found that the E-moduli varied from 110-371 MPa. Other studies examining the E-moduli of permeable subbases based on moisture content were not found. However, this paper discusses different experiences regarding the bearing capacity of traditional vs. permeable subbase materials. It also covers a discussion and an analysis of missing research areas that needs to be investigated for further knowledge about the usage of permeable pavements in areas with a risk of flooding.
\end{abstract}

Keywords: coarse grained aggregate; permeable subbase; permeable pavements; climate change; heavy precipitation; water management; bearing capacity; E-moduli

\section{Introduction}

Climate change is a commonly discussed topic throughout the world. According to the Intergovernmental Panel on Climate Change (IPCC) 2021 and the United Nations World Goals (UN World Goals), the world climate will change rapidly in the next 20 years. Due to an increase in greenhouse gas emissions that block the heat from escaping the atmosphere, the Earth will, on average, become warmer in the future. According to the IPCC's newest report from 2021, the global surface temperature will continue to increase 1.5-2 degrees unless the $\mathrm{CO}_{2}$ concentration decreases [1]. These warmer conditions will lead to evaporation and will cause an increase in the regularity and intensity of natural disasters, e.g., heavy precipitation and reductions in sea ice and permafrost [2].

As the climatic changes depend on human behavior, climatic models have been compiled with different behaviorial scenarios. It is not possible to escape the fact that some changes will occur in the form of heavy precipitations and marine heatwaves even within the scenario where expected emissions are low. As the IPCC writes in their report [2]:

"It is very likely that heavy precipitation events will intensify and become more frequent in most regions with additional global warming. At the global scale, extreme daily precipitation events are projected to intensify by about $7 \%$ for each $1{ }^{\circ} \mathrm{C}$ of global 
warming (high confidence). The proportion of intense tropical cyclones (categories 4-5) and peak wind speeds of the most intense tropical cyclones are projected to increase at the global scale with increasing global warming (high confidence" [2].

Many uncontrollable events have already happened globally. According to [2], areas where observed changes in heavy precipitation depending on human contribution have occurred are approximately half of the whole planet. In the worst case, if the future global warming levels increase by $4^{\circ} \mathrm{C}$ the intensity of heavy rainfall events will increase and will result in approximately $30 \%$ wetter areas globally $[2,3]$.

Events with heavy rainfall that cause flooding and uncontrollable situations where the transportation infrastructure is weakened are a result of the climate changes [2]. Incidents like this happened throughout the summer of 2021, for instance, in Germany, Denmark, Belgium etc., and as human behavior continues to impact the climate changes globally, more of these incidents are predicted. There are several thoughts and tests on how to handle situations similar to these based on civil engineering theories and different experiences globally. This opens up two interesting research cases:

- How should flooding be managed?

- How will the traditional way of doing pavement design change in the future?

As part of this, permeable pavements have been used for urban purposes since the 18th century and in recent years also to handle run-off water. Permeable pavements are constructed with different surface materials per need, such as permeable pavers, pervious concrete, porous drainage asphalt etc., but the main goal is to let the surface water infiltrate from heavy rainfall events and heavy precipitation through the whole pavement construction via permeable subbase materials-also called coarse grained aggregates. The permeable subbase layer can either be used as a reservoir or as temporary storage [4-7].

This paper is a systematic review. The aim of this study is to obtain more knowledge about existing research based on permeable pavements and their subbase materials in comparison to traditional subbase materials. The contribution of this literature review is divided into six sections. Section 2 is the methodology of the systematic review. Section 3 presents how to use permeable pavements and their design factors. Further discussion of the bearing capacity in impermeable pavement design, water in roads and a comparison to permeable pavements is shown in Section 4. A study of stiffness and infiltration rates in different experiences around the world in permeable subbase materials is discussed in Section 5. Experiences with pavement design in Denmark are discussed in Section 6. Lastly, a perspective and an analysis for further work are represented in Section 7.

\section{Research Methodology}

A systematic literature review has been carried out to obtain further knowledge about permeable subbase materials in comparison to traditional subbase materials. The methodology of the review is shown in the PRISMA flow diagram below, in Figure 1.

As shown in Figure 1, five databases were used for this literature review. These databases are listed below:

- American Society of Civil Engineering (ASCE)

- Elsevier

- Materials Science and Engineering

- SCOPUS

- $\quad$ Springer Link 


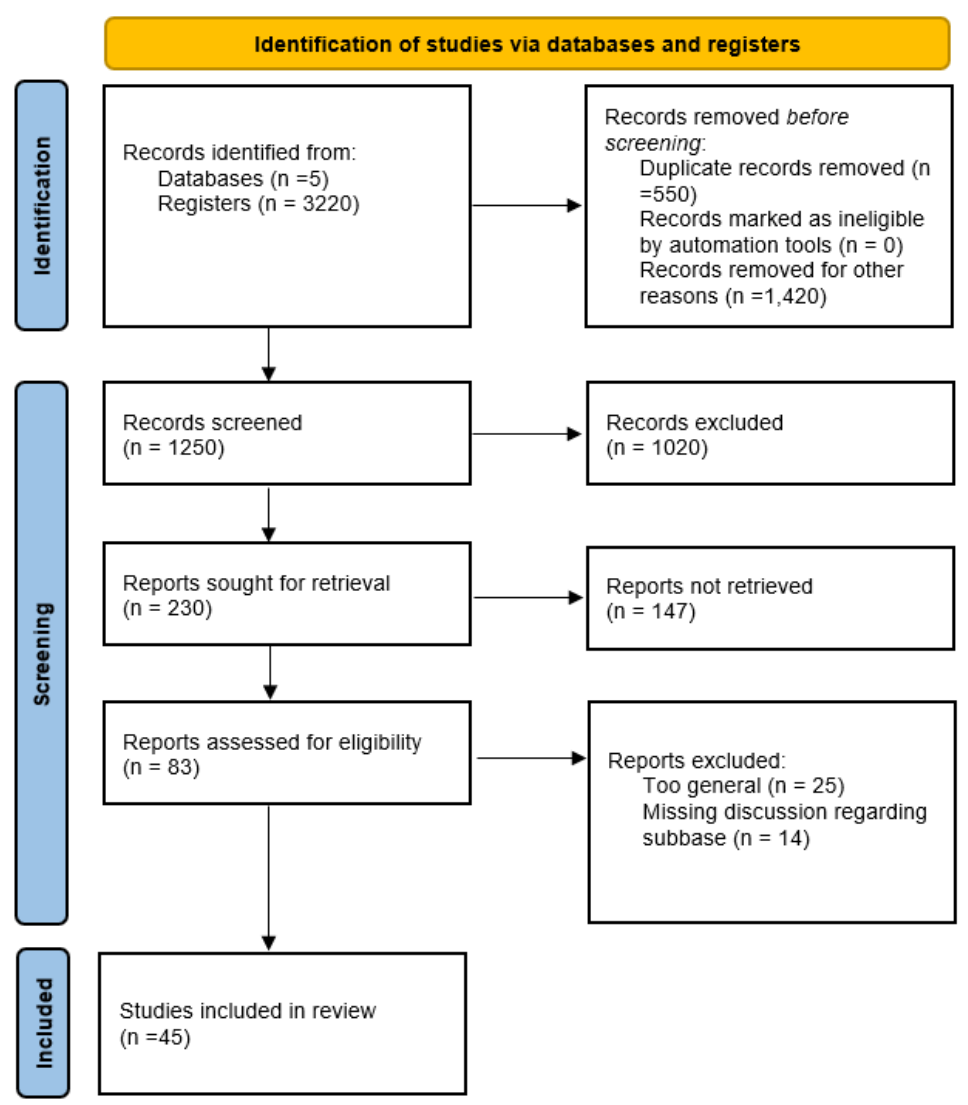

Figure 1. PRISMA flow diagram for the systematic review in this literature review.

After that, three keywords were used to find relevant literature. The keywords are listed below:

(a) "Permeable pavements" AND unbound base materials

(b) "Permeable pavements" AND asphalt

(c) Unbound granular subbase materials

A final screening of the schematic overview of the journal selection together with the keywords for this literature review is shown below in Table 1.

Table 1. Final selected journals together with the search keywords: a, b and c.

\begin{tabular}{llll}
\hline Selected Journals & (a) & (b) & (c) \\
\hline Journal of Mechanical and Civil Engineering & 0 & 1 & 0 \\
Transportation Research Board & 0 & 2 & 0 \\
Journal of Environmental Engineering & 0 & 0 & 1 \\
Journal of Transportation Engineering & 1 & 2 & 0 \\
Journal of materials in Civil Engineering & 0 & 0 & 1 \\
Water management & 0 & 0 & 1 \\
International Journal of Pavement Engineering & 0 & 1 & 1 \\
Road Materials and Pavement Design & 0 & 2 & 0 \\
Construction and Building Materials & 1 & 0 & 0 \\
Springer, book & 1 & 0 & 0 \\
Sustainability & 0 & 0 & 1 \\
Others (theses, dissertations, other journals, etc.) & 5 & 11 & 12 \\
\hline Total & 8 & 19 & 18
\end{tabular}


This screening made it possible to identify themes that could be directly used in the paper. Thereafter, the selected research papers were grouped under the following themes:

1. Permeable pavements-design factors and applications

2. Bearing capacity in impermeable pavement design

3. Permeable subbase materials

4. How to design permeable pavements

The numbers of research papers divided into the themes are shown in the diagram below (Figure 2).

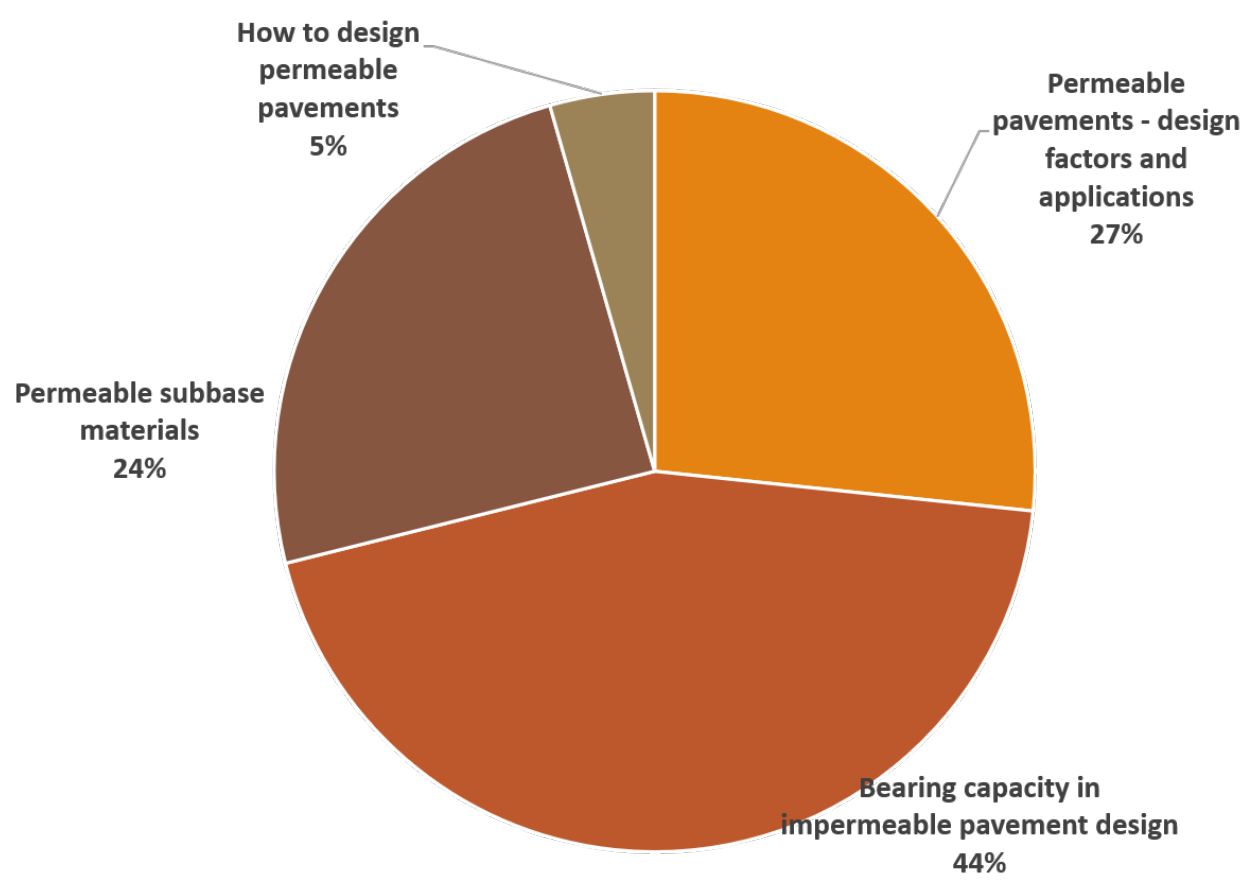

Figure 2. Distribution of useful literature found for this review.

The found literature was evaluated and interpreted according to the themes mentioned above. The final evaluation is discussed as future research needs in this paper.

\section{Permeable Pavements-Design Factors and Applications}

Traditionally, a road pavement is considered as the main part to carry the transport infrastructure without any difficulties and with high accessibility for the specific traffic load. Water is separately handled through drainage systems connected to the road design. The top layer is traditionally a sealed top layer and water is not allowed to enter the subbase materials due to decreased lifespan [8-12].

As a consequence of climate change, urban run-off needs to be sustainably managed to protect (1) from flooding and (2) urban water hydrology. In the 1970s, permeable pavements became an area of interest, especially for countries such as the United States and in many European countries due to increasing rainfall events [13]. This meant a change in thinking, as the existing traditional pavements were built densely and with a low void percentage in the upper layers [4].

Permeable pavements are load bearing pavement structures, which are designed to use the pavement structure as a watersystem. As shown in Figure 3, there are different ways of designing a permeable pavement and it should be noticed that the overall function is the same: water infiltrates via the surface of the pavement $[10,14-17]$.

The actual design and use of materials depend on the load, area and the subgrade soil quality. Depending on the subgrade and the traffic load, either geotextiles or geogrids can be used below the permeable subbase to stabilize the permeable pavement structure. One 
or more geogrids can be used between the permeable subbase for further stabilization. The subgrade is essential before deciding the function of the permeable pavement [18]. The systems can be constructed as described below and shown in Figure $3[15,16,19,20]$ :

1. Full infiltration-the water penetrates through the porous surface and further down to the subgrade, which should consist of mainly sand (or subgrade with very high permeability similar to sand) so the water can pass through the subgrade and further to the groundwater $[10,21]$.

2. Partial infiltration-a combi solution, where the subbase in the pavement structure is used as a reservoir (with overflow) and seepage through subgrade [10,21].

3. No infiltration-the subbase material is used as a reservoir. The subgrade consists of a high percentage of clay and/or silt fractions. The natural soil is therefore impermeable and no infiltration will occur. The subbase material is then used as a reservoir. If the subgrade is permeable and water is not allowed to infiltrate through due to regulations, a waterproof membrane can be placed upon the subgrade before laying out the subbase. The pavement structure is connected to a drainage system $[10,21]$.
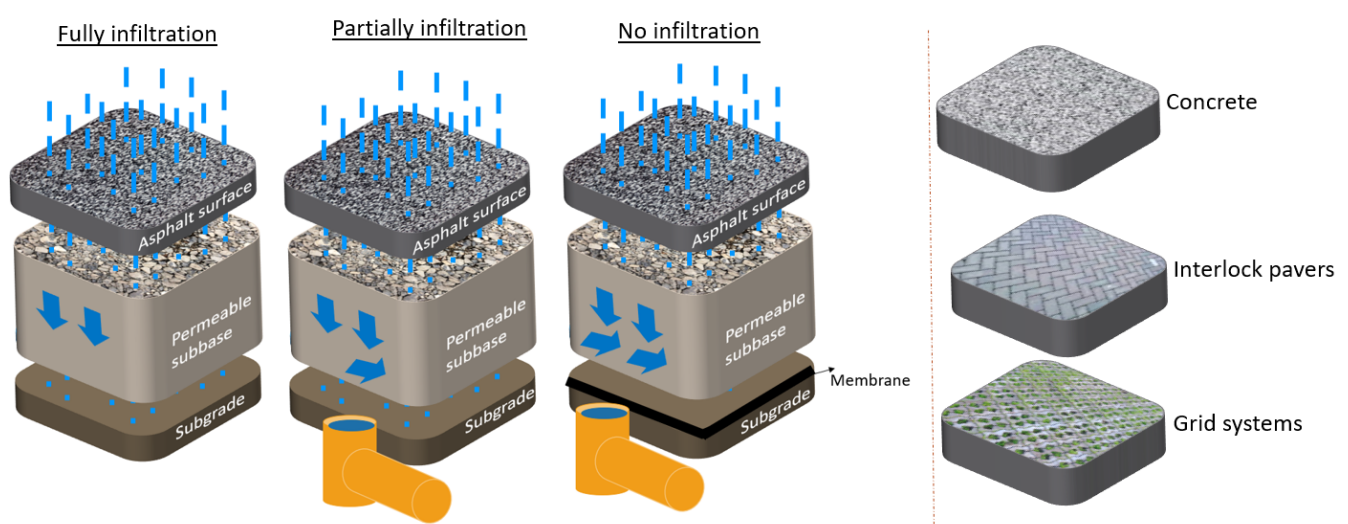

Figure 3. Full infiltration, partial infiltration and no infiltration system. The surface layer can be changed according to the purpose.

As mentioned earlier, the type of top layer varies depending on the desired purpose of the pavement, as shown in Figure 3. As described in different studies $[10,15,22]$, the use of permeable pavements is suitable for local drainage in parking lots, driveways or residential streets/areas. The used applications are summarized in Table 2 below:

Table 2. Different types of permeable pavements.

\begin{tabular}{ll}
\hline Porous asphalt/concrete & $\begin{array}{l}\text { Driveways, residential streets/areas, } \\
\text { low traffic areas, sidewalks }\end{array}$ \\
\hline Interlocking concrete paving & $\begin{array}{l}\text { Parking lots, industrial storage areas, } \\
\text { loading zones, parking pads }\end{array}$ \\
\hline Grid systems & Fire ways, parking pads in low traffic areas \\
\hline
\end{tabular}

\section{Bearing Capacity in Impermeable Pavement Design}

The lifespan and structural performance of a pavement construction is based on its bearing capacity and its corresponding E-moduli. The bearing capacity in a pavement construction depends on the mechanical behavior of each material in the construction [8,23].

Every material in a pavement construction will be affected by a stress regime, as shown in Figure 4, once moving wheel loads pass over the surface of the road $[8,21,24]$. The stress axes will rotate due to stress patterns in every layer of the pavement construction, and this is shown in Figure 5. 

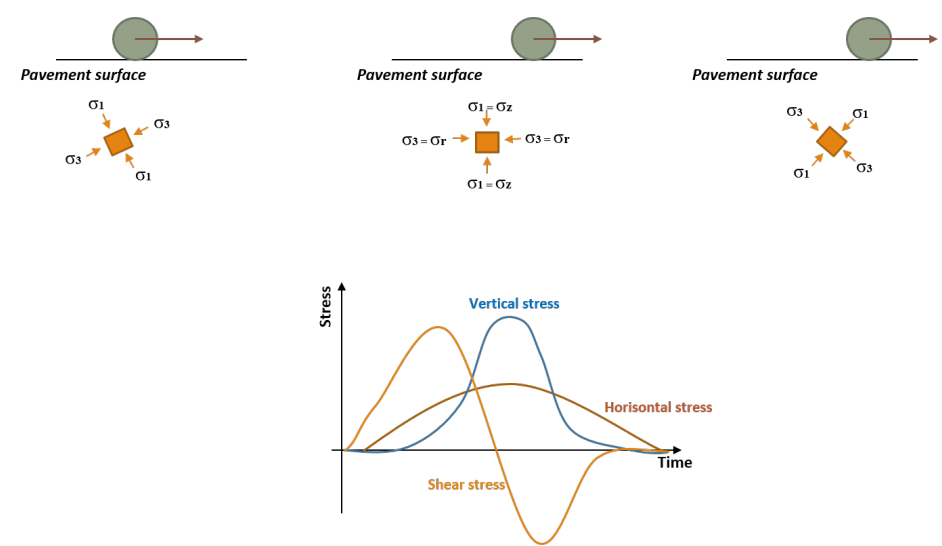

Figure 4. Stress regime in a soil element due to a single moving wheel load. Adapted with permission from [25]. 2021 Fredrick Lekarp.

Every component in a pavement structure incurs vertical, horizontal and shear stresses. In unbound materials, the vertical and the horizontal stresses are positive, and the shear stresses are reversed. This stress regime leads to a deformation of the material, which can be a result of three mechanisms $[21,24,26,27]$ :

- Dilatation-change in shape and compressibility.

- Distortion-sliding and rolling particles.

- Attrition-leading to breakage of the particles as the particles undergo stresses that exceed the strength.

Due to the moving wheel load, the deformation of the material can then be described as a resilient and permanent deformation, as the material is not able to fully recover. This is shown in Figure 5.

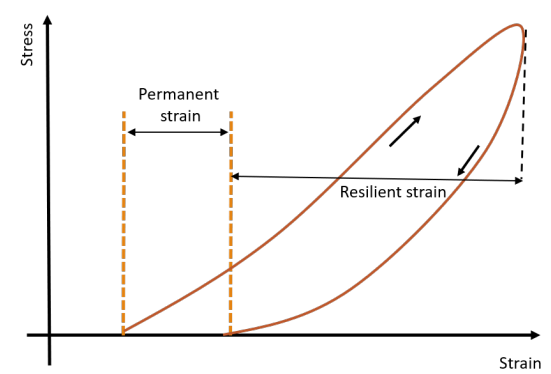

Figure 5. Stress regime in a soil element due to a single moving wheel load. Adapted with permission from [25]. 2021 Fredrick Lekarp.

These deformation characteristics will be highly affected by the presence of water and the three mechanisms might, due to the presence of water, occur sooner than expected. However, the material might also be more sensitive to permanent deformation and show a resilient response with increasing moisture content [28].

\subsection{Water in Roads and Resilient Response}

In general, adding water to a soil specimen could affect the resilient response in two ways depending on the soil type and the amount of water. Partly saturated soils and gravels will have an increase in strength and stiffness, but a further increase in water content will have a negative impact and cause a reduction in strength and stiffness compared to that observed in the beginning stage [25,29-31].

As discussed earlier, and shown in Figure 5, the deformation of an unbound material is caused by a moving wheel. The deformation characteristics will even be highly affected by the presence of water and high moisture content [32-34]. 
The author of [35] describes the resilient modulus as a function of the saturation ratio for well graded materials (as traditional subbase materials). The unbound materials were fully dry and saturated. The unbound material showed the highest resilient modulus at a saturation level of $34 \%$. Increasing the saturation ratio reduced the resilient modulus accordingly. A comparison to different subbase materials, such as a variation in coarse grained materials, is of interest as this might give an overall view.

Different studies indicate that coarse grained subbase materials are less affected by water content and thereby also show less deformation and the E-moduli are less reduced. Unbound materials with a higher content of fine-grained soils, have a higher tendency to show reduced E-moduli and lose bearing capacity faster than normal [21,24,36].

In fact, a significant reduction in E-moduli was noticed when repeating the load triaxial tests with well graded subbase materials with a higher amount of fines content, while the reduction was less in coarse grained aggregates. The ability to recover fully and regain the E-moduli happened soon after drainage $[25,32,33,37]$.

Another study carried out in Denmark, measuring the correlation between the bearing capacity and moisture using a road testing machine (RTM), specifically a falling weight deflectometer (FWD), indicated a significant reduction in E-moduli with increasing moisture content. Then, the deflection and E-moduli were tested on a testfield consisting of $60 \mathrm{~mm}$ asphalt, a $140 \mathrm{~mm}$ granular layer $(0 / 32 \mathrm{~mm})$ and a $420 \mathrm{~mm}$ subbase sand layer on top of a $1 \mathrm{~m}$ subgrade sandy till. The results indicated an increase in pore pressure in all unbound layers. When all the unbound layers were drained after a period of one month, approximately $60 \%$ of the surface moduli were reduced. Even after drainage, the used materials are not able to recover fully, hence the surface moduli are reduced compared to the surface moduli measured once compacted. The fines content in the used materials makes it difficult to recover fully and re-obtain the surface moduli from the original state $[21,24,38]$. Measuring the surface moduli with a FWD is a practical and applicable method. However, it would have been interesting to observe and illustrate the affect of surface moduli in each layer and in comparison to moisture content for each state. A cycle of surface moduli measurements in each stage of moisture content will give a better insight into the material properties.

These different studies stipulate different correlations between pore pressure, moisture and E-moduli in unbound materials used for the subbase. The studies show that increased moisture in unbound materials with a high content of fines leads to increased pore pressure and decreased E-moduli. When a wheel load passes over the surface of the pavement, the pore pressure will be pressed downwards and, by continuous loading, this could lead to permanent deformation $[25,30,39]$.

\subsection{Seasonal Variations}

The top surface of a traditional pavement should be considered as impermeable. The unbound layers, such as subbases that consist of sand and gravel, are permeable layers through which water can easily flow. Depending on the density of the subbase material, the permeability might vary. As the subbase layer has a structural function to distribute the vehicle wheel load to the subgrade soil, water is not supposed to be let into the pavement. The subbase layer should therefore be kept intact and dry so it can carry the load the pavement is designed for. If water enters the pavement design and the subbase, the bearing capacity of the road construction will vary during the seasonal variations in a year, as shown in Figure 6.

When the unbound materials are exposed to freezing temperatures, water will enter the subbase materials and ice crystals will start forming. If the subbase materials are more sensitive to water, the ice crystals will grow until ice lenses are formed [21]. As can be seen in Figure 6, the highest reduction in E-moduli is observed during the beginning of spring thaw season. The water will expand and cause a major reduction in bearing capacity during the thawing period. The stiffness may not be immediately recovered, depending on the fine content in the soil [24,28,40]. Similar situations can be found in [41]. Moisture and deflections 
in the subgrade are compared through the four seasonal variations. A correlation between moisture content and deflections has been described. When moisture content is increasing, the deflections become deeper. When moisture content is fully removed from the subgrade material, the deflection and the bearing capacity are eventually regained [28,42].

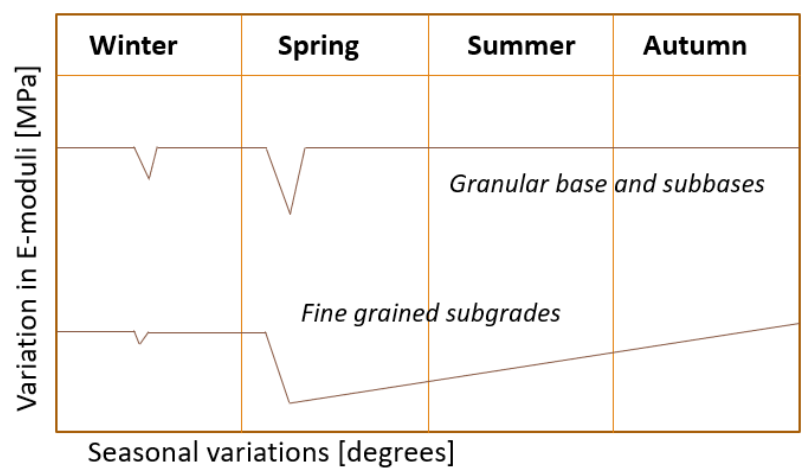

Figure 6. Seasonal variation and effect on granular base, subbases and fine grained subgrades. Inspiration from [28].

\section{Permeable Subbase Materials}

As shown in Section 4, increased moisture content in unbound materials will lead to a negative impact in unbound materials. This is especially seen with unbound materials with more fines content.

Permeable subbase materials are initially built to be used as a reservoir and for water infiltration to happen every time a rain event occurs. Instead of a traditional subbase material which is well graded and shows a high strength and bearing capacity when compacted, the permeable subbase material is an alteration of aggregate materials [28].

The permeable subbase layer is supposed to handle both the hydrological aspect and the bearing load from vehicles. To increase the bearing capacity of the subbase, geotextiles can be laid between two layers to enhance water treatment. However, the use of geotextile could lead to a loss in hydraulic conductivity in the subbase material as the material will lose friction between layers. Instead, geonets can be used to enhance the bearing capacity of the subbase layer $[21,28,43,44]$.

The bearing capacity-corresponding E-moduli and the hydraulic conductivity depend on the porous structure and the compaction structure of the layer [45-48]. Traditionally, a subbase layer used in a traditional pavement follows the rules of the Fuller curve [49] to obtain the optimum bearing capacity for the given subbase layer. According to EN 13285 , the hydraulic conductivity of a permeable subbase should be $\mathrm{k}>5.0 \times 10^{-4} \mathrm{~m} / \mathrm{s}$ for permeable subbase layers. When constructing a permeable layer, the theory of the Fuller curve is not applicable. Porosity is required in a permeable subbase, as water needs to infiltrate as fast as possible through the pavement system. If the subbase layer is well graded and consists of a higher content of fines, the infiltration rate will be lowered and it cannot be categorized as permeable [28,50,51].

\subsection{Stiffness of Permeable Subbase Materials}

Only one study was found on the bearing load of a unbound coarse grained granular material used as a base layer in a permeable pavement [52]. The deformation and resilient E-moduli were tested with a repeated triaxial loading. Moreover, it was found that the E-moduli ranged from 110 to $371 \mathrm{MPa}$ with a porosity of approximately $33 \%$ to $40 \%$. It was found that the stress level, porosity and moisture level had an impact on the deformation of the material. In this study, it was concluded that the bearing capacity of this specific type of unbound coarse grained granular material also met the requirements as a base material under wet conditions. The gradation curves used for this study are shown in Figure 7 below [52]. 


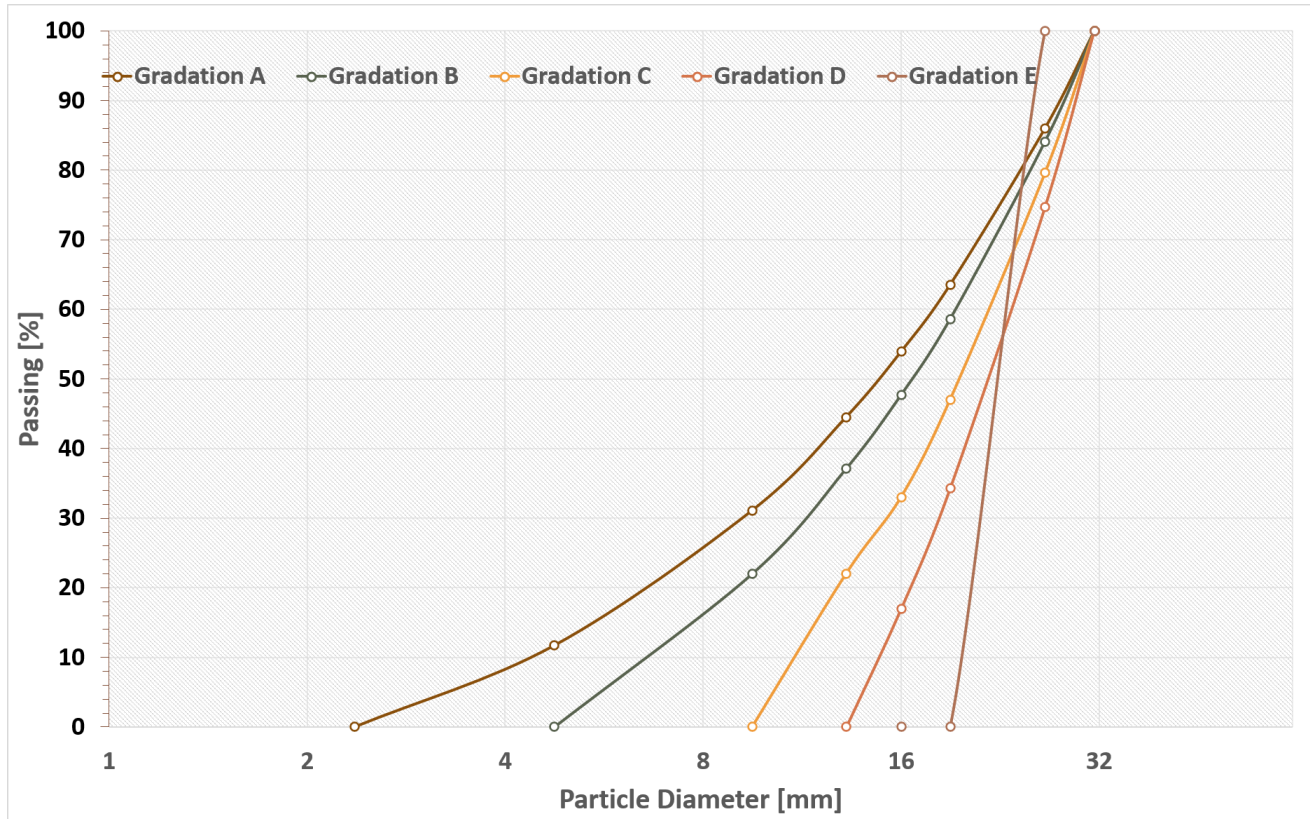

Figure 7. Five different gradation curves for triaxial testing of permeable subbase materials in China [52].

\subsection{Hydraulic Conductivity}

In Figures 8 and 9 below, different coarse graded aggregates from the USA, Spain and Denmark are shown together with the permeability coefficient for all the materials. These studies discuss the permeability of the coarse graded aggregate subbase material, and do not discuss the E-moduli of the material $[28,53,54]$.

The hydraulic permeability coefficient is found by constant head laboratory work and shown in Table 3.

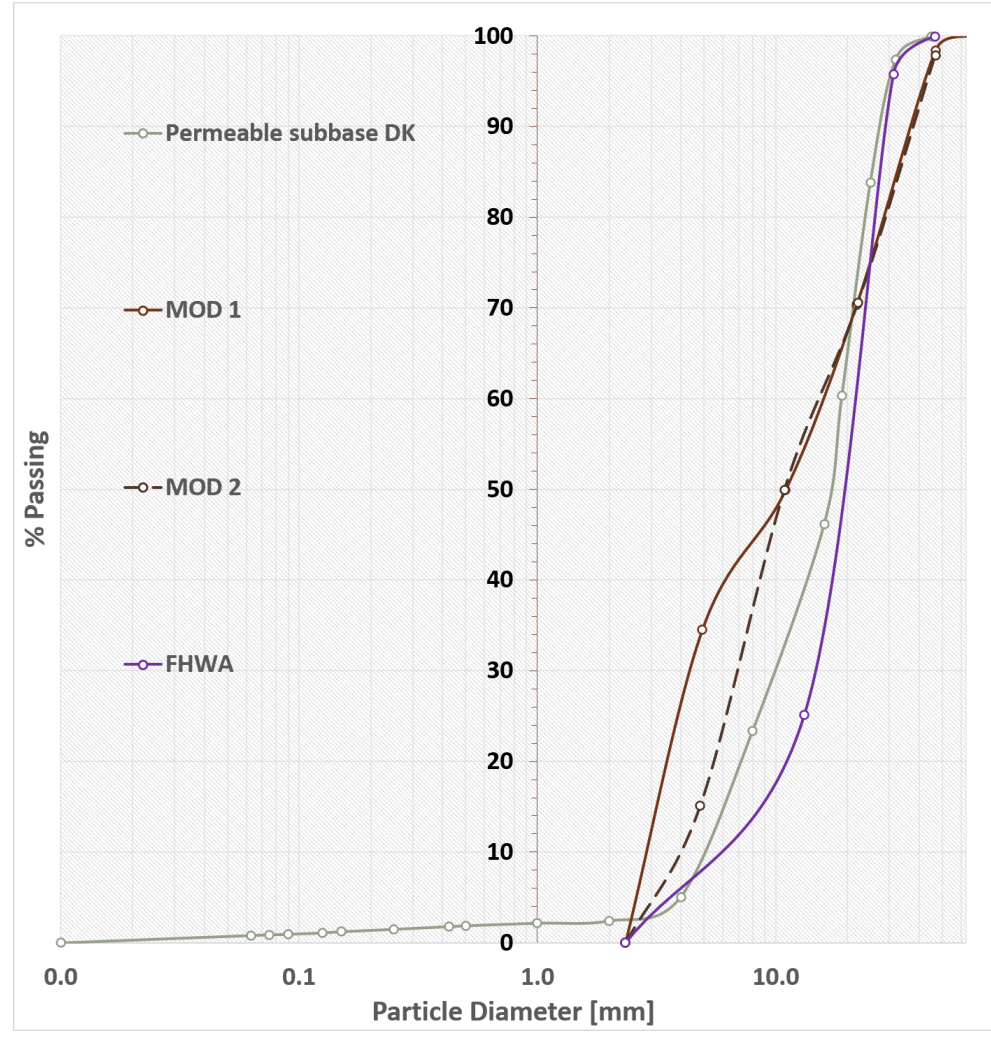

Figure 8. Different experiences with permeable subbase materials $[28,53,55,56]$. 


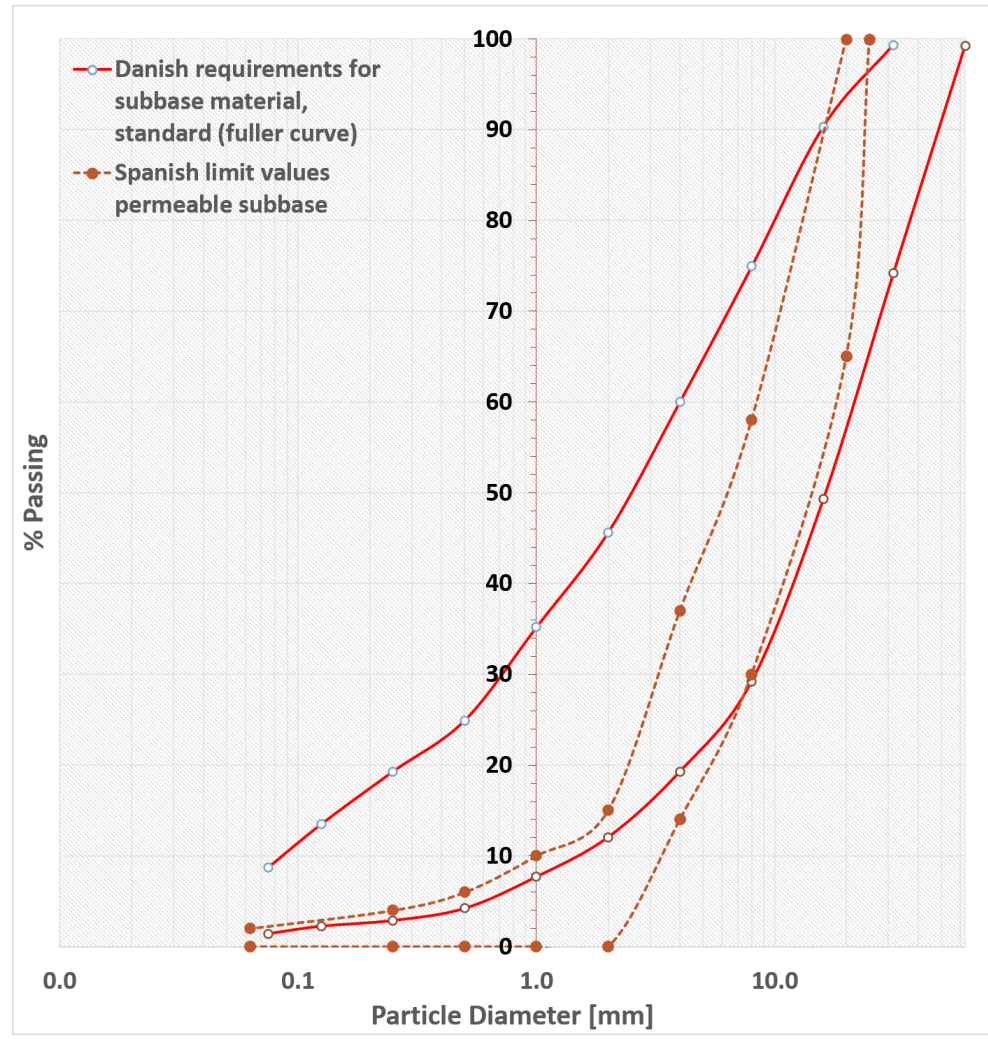

Figure 9. Spanish permeable subbase requirements in comparison to traditional subbase material used in DK-similar to Fuller curve $[28,55]$.

Table 3. Hydraulic permeability coefficient, K, for some of the gradation curves from Figure 8.

\begin{tabular}{cl}
\hline & Permeability, $\mathbf{k}[\mathbf{m} / \mathbf{s}]$ \\
\hline AASHTO & 0.0201 \\
\hline Louisiana & 0.0016 \\
\hline MOD 1 & 0.026 \\
\hline MOD 2 & 0.038 \\
\hline FHWA & 0.058
\end{tabular}

Figure 9 shows the limit curves for a traditional Danish subbase material in comparison to a Spanish permeable subbase material. As shown, the traditional subbase material includes a variation and a greater amount of fines with a maximum of $9 \%$ passing sieve size $0.063 \mathrm{~mm}$. The Spanish limit values used for permeable subbase material are also shown in Figure 9. It is shown that the Spanish gradation curve is very horizontal in the small sieve size range, and in the category open graded. None of the gradation curves shown in Figure 8 fulfill the requirements for a Spanish permeable subbase. However, it should be noted that all the curves are horizontal in the small sieve size range. The gradation curve FHWA consists of a higher amount of bigger aggregates, hence the highest permeability rate is at $0.058 \mathrm{~m} / \mathrm{s}$, whereas MOD1 is less horizontal compared to the others, and therefore consists of a lower permeability rate at $0.0201 \mathrm{~m} / \mathrm{s}$.

The Danish gradation curve for permeable subbase materials consists of a larger amount of particles $<2 \mathrm{~mm}$, as in Figure 8 . The aggregates from the USA consist of aggregates no smaller than $2 \mathrm{~mm}$. Compared to Figure 9, the Spanish limit curves for permeable subbase materials are more similar to the ones used in Denmark, whereas the ones from the USA are more coarse grained. 
Further research on bearing capacity when subbase materials are opposed to water and frost is not documented for these materials [51].

\section{How to Design Permeable Pavements}

A field test study in Sweden indicated that a permeable pavement with a top layer of porous asphalt and a unbound base of macadam was more resistant to freezing compared to a traditional impermeable pavement. The tests indicated that the reason behind it was the higher water content in the soil, which increased the latent heat in the ground. It was also found that the thawing process was slower than in traditional pavements [24,57].

In Denmark, pavements are designed based on frost protection and frost penetration depths [58,59]. According to the Danish pavement design program, MMOPP, a frost penetration model is as shown below:

$$
\text { Frostpenetration }=45 \mathrm{~mm} *(x)^{0.5}+\frac{k}{2}
$$

$x=$ lowest frost degree in a $24 \mathrm{~h}$ period.

$k=$ total pavement thickness.

The pavement design can be calculated either mechanistically or by simulation. Both methods need a factor for the bearing capacity of the specific materials. Looking at the simulation model, a model determining the bearing capacity and E-moduli variations for each seasonal variation is used. These values are shown in Table 4, and the used values are from the Swedish road regulations. The climatic weather data are from Skåne, Sweden. The E-moduli for each layer are then adjusted as shown in Table 4 . It should be noted that no correction has been made regarding the E-moduli for water storage in the presence of water from rainfall events [24,58,59].

The table below indicates how many days a specific temperature per year can be expected. This is a summation of the deterioration which is expected throughout the pavement's lifespan. The E-moduli of all the materials in the pavement construction are unchanged during the summer. During winter, the E-moduli increase up to 10-20 times for the subbase and subgrade layer, respectively. During spring thaw, a reduction in E-moduli of up to $60 \%$ is expected $[24,58,59]$.

As can be seen, water is not taken into account when designing a traditional pavement. As discussed in this literature review, in Section 4, a reduction in the bearing capacity also occurs when water enters fine grained materials.

Table 4. Seasonal variation in the bearing capacity in a road construction from MMOPP 2017, pavement design [59].

\begin{tabular}{lllllll}
\hline Period & Days & Temperature $\left[{ }^{\circ} \mathbf{C}\right]$ & $\mathbf{E}_{\mathbf{1}}$ & $\mathbf{E}_{\mathbf{2}}$ & $\mathbf{E}_{\mathbf{3}}$ & $\mathbf{E}_{\mathbf{m}}$ \\
\hline Winter & 49 & -2 & 4 & 4.2 & 10 & 20 \\
\hline Winter thaw & 10 & 1 & 3.7 & 0.3 & 10 & 20 \\
\hline Spring thaw & 15 & 1 & 3.7 & 0.7 & 0.7 & 0.6 \\
\hline Late spring & 46 & 4 & 3.1 & 1.0 & 0.8 & 0.8 \\
\hline Summer & 143 & 20 & 1.0 & 1.0 & 1.0 & 1.0 \\
\hline Heat wave & 10 & 50 & 0.3 & 1.0 & 1.0 & 1.0 \\
\hline Autumn & 92 & 7 & 2.6 & 1.0 & 1.0 & 1.0 \\
\hline
\end{tabular}

A sensitivity analysis was carried out for a pavement's life cycle based on seasonal variations in E-moduli in MMOPP [60]. The analysis was based on different estimated traffic loadings and two different variations in the subgrade E-moduli at, respectively, $20 \mathrm{MPa}$ and $40 \mathrm{MPa}$. It was concluded in the study that a reduction of $60 \%$ of the pavement's lifespan was seen when the E-moduli of a well graded subbase material were halved. The 
used well graded subbase material followed the gradation curves for Danish requirements of traditional subbase material as shown in Figure 9 [24].

\section{Conclusions}

Due to heavy precipitation, transport infrastructure is in a vulnerable place. Road constructions are facing more water due to heavy rainfall events and road constructions are expected to be able to handle run-off water and traffic loads. This systematic literature review focused on permeable pavements, and especially a comparison of traditional subbase materials and permeable subbase materials.

Compared to traditional subbase materials, it was found that well graded materials with a high content of fines are more likely to be sensitive to increasing moisture content in the material. It was found that if the moisture content increases to more than the optimum water content, a loss in bearing capacity will occur. It was also found that an increase in moisture content and therefore drainage will lead to a permanent deformation of the subbase material, and hence a great loss in bearing capacity was found in different studies, e.g., a field test in Denmark where $60 \%$ of the surface moduli were reduced.

Studies on coarser grained aggregates showed less of an effect by increasing water content.

Only one study was found that focused on the E-moduli of a permeable subbase material [52]. Here, E-moduli of 110-371 MPa were found by triaxial testing.

It can be concluded that only a few studies were found that focused on the bearing capacity and E-moduli of permeable subbase materials. This is a research gap that needs to be explored more.

\section{Future Research Needs}

Permeable pavements are a another way of using the road design directly to handle flooding and heavy precipitation. Although permeable pavements are a simple water system, there are still a large number of unresearched areas. The ones found in this literature review are shown below:

- How the coarse grained aggregate/permeable subbase material reacts in cold regions.

- The bearing capacity of the coarse grained aggregate when constructed in the field and:

- in dry conditions;

- in saturated conditions;

- when the saturation level is higher than what is needed for the compaction;

- in frost and cold weather.

There is a need for further research to investigate the bearing capacity of the coarse grained aggregate. Based on traditional subbase materials and earlier research on them, there is an understanding that the most important part of letting water penetrate through the subbase material is not to increase the pore pressure in the road construction. As pointed out in [51], studies regarding the bearing capacity and E-moduli of unbound permeable subbase materials are too few.

\section{Discussion of Future Research}

In the following, an analysis of future research needs is discussed.

The current pavement calculation method is based on frost protection for traditional pavements. Permeable pavements are a water management method so calculating the lifespan when using the pavement for water storage is very interesting.

As described earlier, MMOPP is a Danish pavement design program. The program does not focus on the specific materials' bearing capacity when affected by water and when the subbase is used for water storage, but is focused on frost protection. In a future perspective, it is of interest to pay extra attention to:

- Weather analysis of how many coherent days are under 0 degrees in the past $<20$ years.

- Weather analysis of rain intensity and precipitation amounts in the past $<20$ years. 
The use of permeable pavements is a water management method. As well as handling the hydraulic aspect, they also have to maintain structural and long-term performance.

The lifespan of a permeable pavement should be calculated depending on heavy precipitation and water storage in relation to the resilient E-moduli. Therefore, research consisting of analyzing surface temperature to show a confirmation of how many coherent days below $0{ }^{\circ} \mathrm{C}$ through all 365 days per year there have been in the past 10-20 years and research looking at the precipitation amounts will help to optimize the calculation method for permeable pavements.

The bearing capacity of the coarse grained aggregate used as a permeable subbase should also be determined.

It was discussed that a study in China [52] showed E-moduli of 110-371 MPa by testing a permeable subbase material with triaxial testing. It would be interesting if the triaxial tests carried out on permeable subbases [52] were compared to a field test where the bearing capacity and E-moduli are measured after the road construction is compacted in the field.

The bearing capacity can only be obtained as predicted in the laboratory work if the degree of compaction fulfills the requirements written in the specific tender document for the specific project. However, a lot of experience with such materials indicates the difficulties in compacting the material in the field during site operations. The subbase material with a coarse graded aggregate mixture forms a bow wave ahead of the construction plant. As discussed earlier, there is a need to determine the bearing capacity of the material in every stage, especially how the resilient the E-modulus behaves when exposed to water and different water levels. This determination will lead to an understanding of the material properties of such a permeable subbase and also help in standardizing the product in the market.

The literature and experience indicate that testing the surface moduli of specific materials can easily be verified by using a falling weight deflectometer (FWD). When measuring the water level in the road construction and the surface moduli measured for each water level, the E-moduli can be expressed according to variations in water levels [61]. This is similar work to the study [62] that focuses on the pore pressure of materials in a permeable pavement in a field test that is under traffic loading.

Frost prevention and how the subbase material acts when exposed to water and frost are also not documented. However, experiences about the surface and clogging in the pores of the surface material during maintenance in both cold and temperate weather situations are documented and described $[63,64]$.

The question is whether the road network can maintain its function if both a rising sea level and an increase in precipitation are expected. If the road network is not adapted to the coming climate and heavy rainfall events, the probability of the water volume resulting in floods is high. This will lead to economical consequences. Therefore, further research into this is of importance.

Author Contributions: The first author, D.V.M., wrote the entire draft version of the paper and revised it according to comments from the E.K. All authors have read and agreed to the published version of the manuscript.

Funding: This research was funded by the Innovation Fund Denmark grant number 1044-00063A, and by WSP Denmark A/S as part of an industrial PhD.

Institutional Review Board Statement: Not applicable.

Informed Consent Statement: Not applicable.

Acknowledgments: This research was supported by grants from the Innovation Fund Denmark, for the Industrial PhD program between following partners: WSP Denmark A/S and Aalborg University.

Conflicts of Interest: The authors declare no conflict of interest. 


\section{References}

1. Vaz, I.C.M.W.; Ghisi, E.; Thives, L.P. Stormwater Harvested from Permeable Pavements as a Means to Save Potable Water in Buildings. Water 2021, 13, 1896.

2. Masson-Delmotte, V.; Zhai, P.; Pirani, B.; Connors, S.L.; Péan, C.; Berger, S.; Caud, N.; Chen, Y.; Goldfarb, L.; Gomis, M.I.; et al. IPCC, 2021: Summary for Policymakers. In Climate Change 2021: The Physical Science Basis. Contribution of Working Group I to the Sixth Assessment Report of the Intergovernmental Panel on Climate Change; Cambridge University Press: Cambridge, UK, 2021; pp. 1-3949.

3. Climate-Energy and Building Ministry. Fremtidige Klimaforandringer i Danmark; Danmarks Klimacenter Rapport; DMI: Copenhagen, Denmark, 2014; pp. 1-35. ISBN 978-87-7478-652-8

4. Gerald, H. Performance Survey on Open-Graded Friction Coarse Mixes; NCHRP Synthesis of Highway Practice.: Washington, DC, USA, 2000; Chapters 1, 3 and 5.

5. Hansen, K. Porous Asphalt Pavements for Stormwater Management; National Asphalt Pavement Association: Greenbelt, MD, USA, 2008.

6. Harvery, J.; Shan, S.; Li, D.; Jones, J.; Wu, R. Fully Permeable Pavement for Stormwater Management: Progress and Obstacles to Implementation in California; University of California: Berkeley, CA, USA, 2017.

7. Muttuvelu, D.V.; Nielsen, B.N.; Lund-Jensen, B.B. Optimering af drænasfalt. Trafik og Veje 2019, 6-7, 58-60.

8. Adlinge, S.S.; Gupta, A.K. Pavement Deterioration and its Causes. J. Mech. Civ. Eng. 2018, 10, 9-15.

9. Brown, S.F. Soil Mechanics in Pavement Engineering. Géotechnique 1996, 46, 383-426. [CrossRef]

10. Danish Road Directorate; COWI A/S. Permeable Belægninger; Ministry of Transportation: Copenhagen, Denmark, 2015; pp. 1-98.

11. Whittington, J.S.; White, T.D. Evaluation of the Effectiveness of Drainage Layers; Mississippi Transportation Research Center: Austin, TX, USA, 2007.

12. Raeesi, R.; Soltani, A. Mechanical Performance of Tire-Derived Aggregate Permeable Pavements Under Live Traffic Loads. In Advances in Transportation Geotechnics IV; Springer: Berlin/Heidelberg, Germany, 2022; pp. 515-528.

13. Kline, L. Comparison of Open Graded Friction Coarse Mix Design Methods Currently Used in the United States. Master's Thesis, Glemson University, Clemson, SC, USA, 2010.

14. Andersen, C.T.; Foster, I.D.L.; Pratt, C.J. The role of urban surfaces (permeable pavements) in regulating drainage and evaporation: Development of a laboratory simulation experiment. Hydrol. Process. 1999, 13, 597-609. [CrossRef]

15. Beecham S.; Myers B. Structural and design aspects of porous and permeable block pavement. J. Aust. Ceram. Soc. 2007, 43, 74-81.

16. Beecham, S.; Pezzaniti, D.; Kandasamy, J. Stormwater treatment using permeable pavements. Water Manag. 2010, 165, 161-170. [CrossRef]

17. Scholz, M.; Grabowiecki, P. Review of Permeable Pavement systems. Build Environ. 2007, 42, 3830-3837. [CrossRef]

18. Cui, L.; Bhattacharya, S. Choice of aggregates for permeable pavements based on laboratory tests and DEM simulations. Int. J. Pavement Eng. 2015, 18, 160-168. [CrossRef]

19. Brown, R.A.; Borst, M. Evaluation of surface infiltration testing procedures in permeable pavement systems. J. Environ. Eng. 2014, 140, 04014001. [CrossRef]

20. Knapton, J.; Morrel, D.; Simeunovich, M. Structural Design Solutions for Permeable Pavements. In Proceedings of the 10th International Conference on Concrete Block Paving, Shanghai, China, 24-26 November 2012.

21. Muttuvelu, D.V. Permeable Pavements-Analysis of Unbound Permeable Subbase Material. Master's Thesis, Aalborg University, Aalborg, Denmark, 2018.

22. Lucke, T. Using Drainage Slots in Permeable Paving Blocks to Delay the Effects of Clogging: Proof of Concept Study. Water 2014, 6, 2660-2670. [CrossRef]

23. Cetin, A.; Kaya, Z.; Cetin, B.; Aydelik, A.H. Influence of laboratory compaction method on mechanical hydraulic characteristics of unbound granular base materials. Road Mater. Pavement Des. 2014, 15, 220-235. [CrossRef]

24. Brodersen, R. Consequences of Extreme Precipitation for the Deterioration of Road Constructions. Master's Thesis, Aalborg University, Aalborg, Denmark, June 2013.

25. Lekarp, F.; Isacsson, U.; Dawson, A. State of the art. i: Resilient response of unbound aggregates. J. Transp. Eng. 2000, 126, 66-75. [CrossRef]

26. Allaart, A.P. Design Principles for Flexible Pavements, a Computational Model for Granular Basis. Ph.D. Thesis, Technische Universiteit Delft, Delft, The Netherlands, 1992.

27. Allen, J.J.; hompson, M.R. Resilient response of granular materials subjected to time dependent lateral stresses. Transp. Res. Board 1974, 510, 1-13.

28. Dawson, A. Water in Roads Structure-Movement, Drainage and Effect; Springer: Berlin/Heidelberg, Germany, 2008; ISBN 978-1-4020-8561-1.

29. Kamal, M.A.M.; Dawson, A.R.; Farouki, O.T.; Hughes, D.A.B.; Sha'at, A.A. Field and laboratory evaluation of the mechanical behaviour of unbound granular materials in pavements. Transp. Res. Rec. 1993, 1406, 88-97.

30. Lekarp, F.; Isacsson, U.; Dawson, A. State of the art. ii: Permanent strain response of unbound aggregates. J. Transp. Eng. 2000, 126, 76-83. [CrossRef]

31. Sangsefidi, E.; Wilson, J.D.; Larkin, J.T.; Black, M.P. The Role of Water in Unbound Granular Pavement Layers: A Review. Transp. Infrastruct. Geotechnol. 2019, 6, 289-317. [CrossRef] 
32. Ovesen, N.K.; Leif Fuglsang, G.B.; Krogsbøll, A. Lærebog i Geoteknik; Polyteknisk Forlag: Lyngby, Denmark, 2012; ISBN 978-87502-1042-9.

33. Rahman, S.M.; Erlingsson, S. Influence of Post Compaction on the Moisture Sensitive Resilient Modulus of Unbound Granular. Int. Conf. Transp. Geotech. 2016, 143, 929-936. [CrossRef]

34. Tamrakar, P.; Nazarian, S. Moisture effects on moduli of pavement bases. Int. J. Pavement Eng. 2019, 22, $1410-1422$.

35. Kolisoja, P. Large Scale Dynamic Triaxial Tests with Coarse Grained Aggregates. In Proceedings of the 4th International Conference, Bearing Capacity of Roads and Airfields, Minneapolis, MN, USA, 17-21 July 1994.

36. Ekblad, J.; Isacsson, U. Influence of water on resilient properties of coarse granular materials. Road Mater. Pavement Des. 2006, 7, 369-404. [CrossRef]

37. Kolisoja, P. Resilient Deformation Characteristics of Granular Materials. Ph.D. Thesis, Tampere University of Technology, , Tampere, Finland, 1997.

38. Danish Road Directorate. Bearing Capacity and Water; Ministry of Transportation: Copenhagen, Denmark, $1995 ;$ pp. 1-211.

39. Kancherala, A. Resilient Modulus and Permanent Deformation Testing of Unbound Granular Materials. Master's Thesis, Texas University, Austin, TX, USA, August 2004.

40. Ashteyat, A. Characterization of Drainable Base and Subbase Materials. Ph.D. Dissertation, The University of Akron, Akron, OH, USA, 2004.

41. Savard, Y.; de Blois, K.; Bontonnet, M.; Hornych, P.; Manduit, C. Analysis of seasonal bearing capacity correlated to pavement deformation in cold regions. In Proceedings of the 7th International Conference on the Bearing Capacity of Roads, Railways \& Airfields, Trondheim, Norway, 27-29 July 2005.

42. Ba, M.; Fall, M.; Sall, O.A.; Samb, F. Effect of Compaction Moisture Content on the Resilient Modulus of Unbound Aggregates from Senegal (West Africa). Geomaterials 2012, 2, 19-23. [CrossRef]

43. Boogaard, F.; Lucke, T.; Beecham, S. Effect of age of permeable pavements on their infiltration function. Clean-Soil Air Water 2014, 42, 146-152. [CrossRef]

44. Drake, J.A.P.; Bradford, A.; Marsalek, J. Review of environmental performance of permeable pavement systems: State of the knowledge. Water Qual. Res. J. Can.-IWA Publ. 2013, 48, 203-221. [CrossRef]

45. Hernandez-Rodriquez, J.; Castro-Fresno, D.; Fernández-Barrera, A.; Vega-Zamanillo, Á. Characterization of Infiltration Capacity of Permeable Pavements with Porous Asphalt Surface Using Cantabrian Fixed Infiltrometer. Am. Soc. Civ. Eng. 2012, 17, 597-603.

46. Isa, M. Unbound Pavement Base Coarses Parallel Study of Stiffness and Drainage Characteristics. Ph.D. Thesis, Louisiana Tech Univeristy-UMI, Ruston, LA, USA, 1999.

47. Razzaghmanesh, M.; Beecham, S. A Review of Permeable Pavement Clogging Investigations and Recommended Maintenance Regimes. Water 2018, 10, 337. [CrossRef]

48. Young, C.F. Predicting physical clogging of porous permeable pavements. J. Hydrol. 2019, 481, 48-55. [CrossRef]

49. Zentar, R.; Dubois, V.; Abriak, N.E. Mechanical behaviour and environmental impacts of a test road built with marine dredged sediments. Resour. Conserv. Recycl. 2008, 52, 947-954. [CrossRef]

50. Kazemi, F.; Hill, K. Effect of permeable pavement basecoarse aggregates on stormwater quality for irrigation reuse. Ecol Eng. 2015, 77, 189-195. [CrossRef]

51. Kurupou, U.; Rahman, A.; Rahman, M.A. Permeable pavement as a stormwater best management practice: A review and discussion. Environ. Earth Sci. 2019, 78, 1-20. [CrossRef]

52. Guibao, M.; Li, H.; Yang, B.; Zhang, H.; Li, W. Investigation on the deformation behavior of open-graded unbound granular materials for permeable pavement. Constr. Build. Mater. 2020, 260, 119800-119811.

53. NCC. Permeable bæRelag: DrænStabil og DrænAf. Available online: https://www.ncc.dk/vi-tilbyder/rastoffer/produkter/ dranstabil-og-dranaf/ (accessed on 4 October 2021).

54. Andrés-Valeri, V.C.; Marchioni, M.; Sanudo-Fontaneda, L.A.; Giustozzi, F.; Becciu, G. Laboratory assessments of the inflltration capacity reduction in clogged porous mixtures surfaces. Sustainability 2016, 8, 751. [CrossRef]

55. Berg, F. Nye vejregler for stabilt grus og bundsikring. Dansk Vejtidskrift 2004, 22-25. Available online: https://bibliotek.dk/da/ work/870971-tsart:87846563 (accessed on 13 December 2021).

56. Tan, S.A.; Fwa, T.F.M.; Han, C.-T. Clogging Evaluation of Permeable Bases. J. Transp. Eng. 2003, 129, 309-314. [CrossRef]

57. Bäckström, M. Ground temperature in porous pavement during freezing and thawing. J. Transp. Eng. 2000, 126, 375-381. [CrossRef]

58. Busch, C.; Brask, M. LAR belægninger Undersøgelse af levetider ved MMOPP simulation. Vejtidsskrift 2016, 30-33. Available online: https:/ / bibliotek.dk/eng/work/870971-tsart\%3A36940913 (accessed on 13 December 2021).

59. Danish Road Directorate. MMOPP Dimensioneringsprogram for Vejbefæstelser; Ministry of Transportation: Copenhagen, Denmark, 2017; pp. 1-108.

60. COWI A/S. Følsomhedsanalyse for MMOPPk; Internal Document; Vejregel Arbejdsgruppe: Lyngby, Denmark, $2009 ;$ p. 21.

61. Hildebrand, G.; Baltzer, S. Sammenligning af Statisk Pladebelastning, Faldlod og Mini-Faldlod; Vejdirektoratet: Copenhagen, Denmark, 2003.

62. Lu, G.; Törzs, T.; Liu, P.; Zhang, Z. Dynamic Response of Fully Permeable Pavements: Development of Pore Pressures under Different Modes of Loading. J. Mater. Civ. Eng. 2020, 32, 04020160. [CrossRef] 
63. Lebens, M.A.; Troyer, B. Porous Asphalt Pavement Performance in Cold Regions; Minnesota Deparment of Transportation: Saint Paul, MN, USA, 2012.

64. Vaz, I.C.M.W.; Ghisi, E.; Thives, L.P. Simulation on Water Flow in Permeable Pavement Influenced by Voids Decrease. J. Transp. Eng. Part B Pavements 2022, 148, 04021075. 